\title{
Supreme Court date set for weed growers
}

$\mathrm{T}$ he British Columbia federal court challenge of the new national laws preventing medicinal marijuana users from growing their own weed will be heard at the Supreme Court of Canada in February 2015. Health Canada's new rules on medical marijuana, which came into effect Apr.1, require patients to obtain marijuana from official licensed suppliers. Under the previous regulations users could grow weed themselves or designate someone else to grow it.

But this aspect of the new rules are now on hold following a federal court challenge by four British Columbia residents. On Mar. 21, federal Judge Michael Manson granted an injunction to medical marijuana users across Canada who held permits to grow plants under the previous regime. The injunction will stay in place until the Supreme Court of Canada decision. That threeweek long court case, which begins Feb. 23, 2015, will rule on the personal production of marijuana and the production through designated growers.

Meanwhile, all private growers who hold a valid Authorization to Possess, a Designated-person Production Licence or a Personal-use Production Licence as of Sept. 30, 2013, can temporarily continue to grow their own marijuana.

Health Canada's main reasons for creating the new regulations are to improve public safety and the quality of dried marijuana. In its defence statement at the BC Federal Court, Health Canada wrote that growing marijuana in a home poses safety concerns such as fires and mould growth. In addition, growing for personal use has resulted in overproduction, thus people are in possession of illegal amounts of marijuana. Another major concern is that people who produce their own marijuana at home are much more at risk for violent home invasions.

In his ruling, Manson cited $R$ v. Parker [2000], which recognized the requirement of the government to provide reasonable access to marijuana for medical purposes.

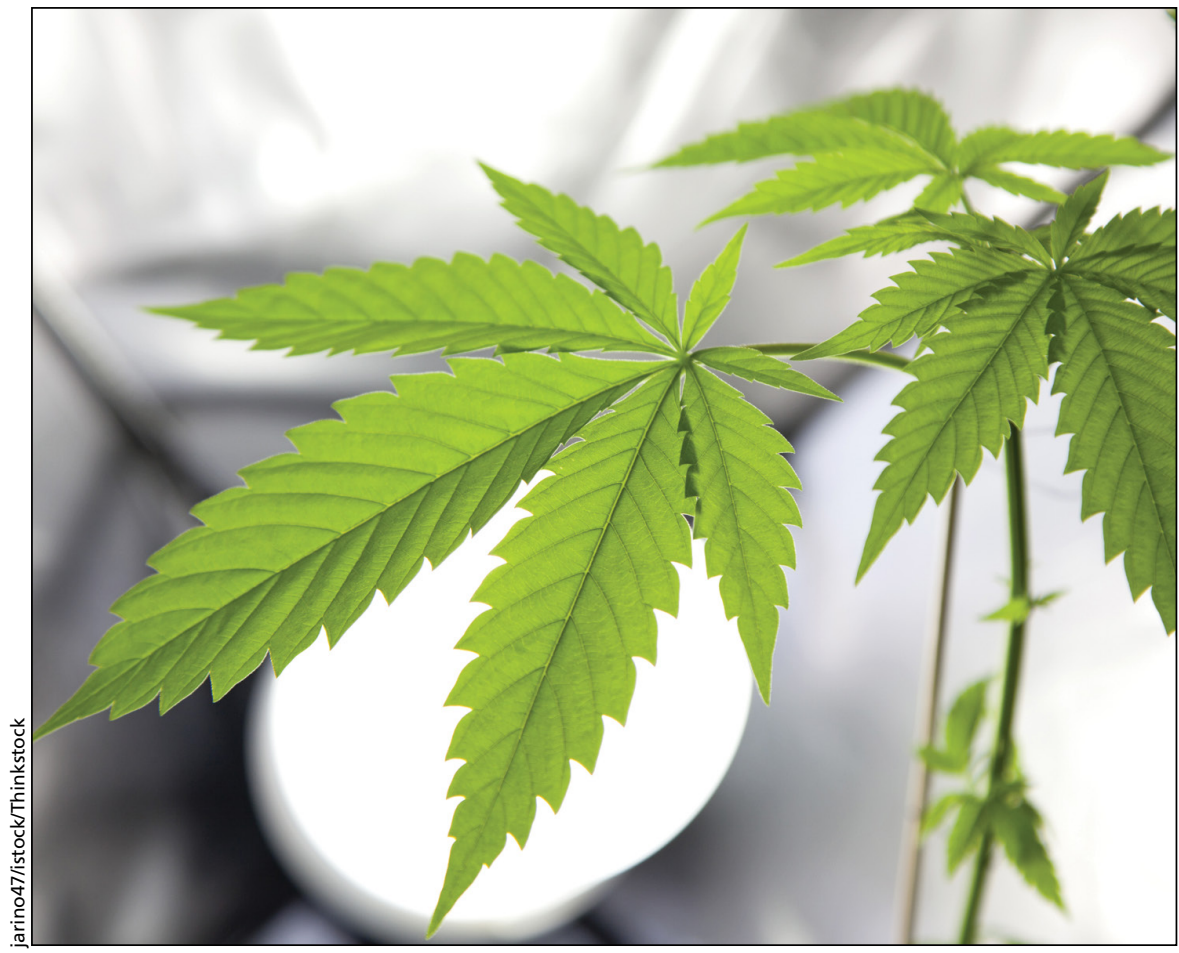

New laws requiring patients to obtain marijuana from official licensed suppliers were successfully challenged in British Columbia. The case now awaits a Supreme Court of Canada decision.

The applicants/plaintiffs in the case argued that their rights under section seven of the Canadian Charter of Rights and Freedoms to liberty and security of the person had been violated by the new regulations. With the typical costs of marijuana falling from $\$ 8$ to $\$ 12$ from licensed producers, the applicants said they would not be able to afford to buy solely from the new licensed producers and would therefore have to do without or resort to illegal purchases. Their lawyer, John Conroy, said that this would necessitate making difficult decisions between their health and acting within the law.

"It causes them to choose between their liberty on one hand and their health on the other. You grow the medicine anyway at risk of being arrested or you do not get the medicine that the doctor has approved for you," Conroy told CMAJ.

Manson found that the applicants had proved they could not afford mari- juana from the licensed producers. He stated in the court decision that "this inability will likely affect either their health, endanger their liberty, or severely impoverish them."

The applicants also stated that their security of the person had been violated through the regulation by forcing them to choose between their personal health and liberty. Conroy says security of the person can include psychological stress imposed by the state.

In his decision, Manson stated, "I find that the nature of the irreparable harm that the Applicants will suffer under the [Marihuana for Medical Purposes Regulation] constitutes a 'clear case,' which outweighs the public interest in wholly maintaining the enacted regulations which are presumed to, among other things, increase the health, safety and security of the public." - Michaela Kostron, CMAJ

CMAJ 2014. DOI:10.1503/cmaj.109-4829 